\title{
Factors that Influence the Rate of Unemployment in Indonesia
}

\author{
Erna A. R. Puspadjuita ${ }^{1}$ \\ ${ }^{1}$ STIE APRIN, Palembang, Indonesia \\ Correspondence: Priyono, Graduate Program Master of Management, Universitas Bina Darma, Palembang, \\ Indonesia. Tel: 62-812-1697-4878. E-mail: priyono.unu_sidoarjo@yahoo.com
}

Received: January 19, 2017

doi:10.5539/ijef.v10n1p140
Accepted: February 14, 2017

Online Published: November 10, 2017

\begin{abstract}
This research was aimed at analyzing the effect of urbanization, industrialization, labor force level, the elasticity of labor force and minimum regional wage rate in Indonesia. The analysis technique used were descriptive and multiple linear regression. The result on $\alpha=5 \%$ shows that the labor force variable was significant to unemployment level in Indonesia. Industrialization shows a positive effect and non-significant to unemployment level, it means that the capability of industrial sector is lower in reducing unemployment compared with agricultural sector and service sector. The elasticity of labor force is negative and non-significant to unemployment sector. The result of regression shows that the elasticity of labor force is non-significant to unemployment level. The variable of minimum regional wage rate shows negative effect and non-significant to unemployment level means that the wage rate is not invisible.
\end{abstract}

Keywords: unemployment, Indonesia

\section{Introduction}

Population is an important production factor in the business of producing goods and services, to develop economic activities. Unlike some other factors of production, labor is very sensitive to economic change. Rapid economic development in an area, will be an attraction for the workforce. Conversely, delays in economic development in a particular region can be a driving force for the workforce to get out of the area.

Positive economic growth will have a positive effect on employment issues. Conversely, negative growth will cause unemployment. For example, when Indonesia's economic growth declines after a monetary crisis, almost all sectors of employment terminate. Workers lost their jobs due to the company's roll-out and the growing unemployment rate. IMF experts estimate (research results, Sriwijaya University cooperation and Department of Manpower, 1998) with negative economic growth in 1998 (minus 4\%) unemployment increased by about 1.6 million people, coupled with 2.7 million new workforce who cannot absorbed in the labor market. According to Jacob Nuwa Wea (in Tempo Interactive Magazine, Jakarta, 2002) to date the number of unemployed in Indonesia reaches 38.3 million workforce, 30.2 million of whom are open unemployed, the rest are half unemployed.

This period of economic crisis is expected to continue until now. BPS (2001) figures show the unemployment rate in 2000 reached $5.03 \%$, where the urban unemployment rate is greater than the rural (Table 1).

Table 1. Labor force, job seeker and unemployment rate according to the 2000 dwelling place of Indonesia

\begin{tabular}{lccc}
\hline Place area Stay & Workforce (people) & Searchers Work (people) & Unemployment rate \\
\hline Urban & 38.298 .608 & 2.459 .241 & $6,42 \%$ \\
Rural & 59.134 .517 & 2.445 .411 & $4,14 \%$ \\
Total & 97.433125 & 4.904652 & $5,03 \%$ \\
\hline
\end{tabular}

Source: BPS, Jakarta 2001.

In urban unemployment rates are greater than in rural areas. According to Prayitno (1996, p. 144) this is due to development programs in urban areas more capital-oriented investment oriented, especially on private businesses. Capital-intensive investments tend to use high technology. Industrialization strategies that rely heavily on capital accumulation and high technology have led to polarization and dualism in the development process (Kuncoro, 1987, p. 181). 
Dualism in development shows a modern and productive manufacturing sector coexisting with traditional and less productive agricultural sectors. However, in the absorption of labor the role of industrial sector is still low, only by $8.2 \%$; far below the role of agriculture sector (47.2\%) and other sectors (44.63\%) can be seen in Table 2 . Labor that is not accepted in the industrial sector will run into the urban informal sector. Thus Lewis's statement that excess labor in the agricultural sector can be diverted and contribute to the urban industrial sector, in reality in developing countries, is very limited.

Table 2. Distribution of work by field or sector Indonesia's work in 2000

\begin{tabular}{llcc}
\hline \multicolumn{2}{l}{ Field $/$ Job Sector } & Amount & $(\boldsymbol{\%})$ \\
\hline 1. & Agriculture & 43.605 .194 & $47,17 \%$ \\
2. & Industry & 7.578 .953 & $8,20 \%$ \\
3. & Other sectors & 41.267 .625 & $44,63 \%$ \\
Amount & & 92.451 .772 & $100 \%$ \\
\hline
\end{tabular}

Source: BPS 2015. Population of Indonesia: (processed from research data).

There is a tendency of the informal sector to cope with unemployment. According to Hananto Sigit (in Effendi, 1995, p. 74) despite the shift of labor from the agricultural sector to non-agricultural sector during the last twenty years, but employment entering the workforce is non-agricultural work classified informal. In Indonesia the role of the informal sector in the absorption of manpower is quite high at $64.28 \%$ in $2000: 77.80 \%$ in rural and $42.88 \%$ in urban areas. The magnitude of the role of the informal sector, in the absorption of labor is one of the factors of unemployment rate in Indonesia, especially in rural areas is quite low. This can be seen in Table 3.

Table 3. Number and distribution of workers by employment status and residential areas, Indonesia in 2015

\begin{tabular}{lcccccc}
\hline \multirow{2}{*}{ JOB STATUS } & \multicolumn{2}{c}{ Urban } & \multicolumn{2}{c}{ Rural } & \multicolumn{2}{c}{ Urban+ Rural } \\
\cline { 2 - 6 } & Amount & \% & Amount & \% & Amount \\
\hline I. Formal Sector & 20442788 & 57,12 & 12572731 & 22,20 & 33015519 & 35,72 \\
2. Informal Sector & 15345986 & 42,88 & 44054418 & 77,80 & 59400404 & 64,28 \\
Total & $\mathbf{3 5 7 8 8 7 7 4}$ & $\mathbf{1 0 0 , 0 0}$ & $\mathbf{5 6 6 2 7 1 4 9}$ & $\mathbf{1 0 0 , 0 0}$ & $\mathbf{9 2 4 1 5 9 2 3}$ & $\mathbf{1 0 0 , 0 0}$ \\
\hline
\end{tabular}

Source: BPS 2015. Population of Indonesia: (processed from research data).

The urban informal sector has been regarded as the safety valve for the labor boom coming from the countryside. However, according to Hart's research results (Tadjuddin, 1995, p. 83) the capacity of the informal sector for some cities has decreased, eg. Jakarta. If the capacity of the informal sector has saturated, then the possibility of open unemployment in the future becomes greater. The high unemployment rate is open, one of which is contributed by educated unemployment.

The results of Clignet's research in Africa (Lizferina, 2000) suggest that the more educated one, the greater his expectation on the type of safe work. Symptoms are among others caused by the desire to choose a safe job of risk. Thus they prefer to choose unemployed rather than get a job that is not in accordance with their wishes. This Clignet study can be used to determine the increasing symptoms of educated unemployment in Indonesia.

As proof of educated unemployment is concentrated in the labor force group with high school education reaching $9.94 \%$ and University $6.91 \%$. It is not known exactly whether the concentration of educated unemployment is due to their preference for unemployment or because they have not yet been accepted into the job.

Table 4. Labor force, job seeker and level unemployment by education Indonesia in 2015

\begin{tabular}{ccccc}
\hline Education & Workforce & Job seekers & Unemployment \\
\hline < Elementary School & 22.755 .279 & 393.414 & $1,73 \%$ \\
Elementary School & 39.505 .024 & 1.434526 & $3,65 \%$ \\
Junior High School & 13.505 .024 & 1.032 .013 & $7,64 \%$ \\
Senior High School & 17.493 .825 & 1.738 .811 & $9,94 \%$ \\
University & 4.408 .156 & 304.504 & $6,91 \%$ \\
\hline
\end{tabular}

Source: BPS, Jakarta 2015 
More detailed Cobbe (Syamsuddin, 1993, p. 47) states there are three factors that are suspected to cause high levels of unemployed educated labor. First, the mismatch between characteristics entering the labor market with the available jobs. Second, expectation of higher returns from offered bids and a slow adjustment process on some new workforce. Third, inefficient market function, imperfect and non-current information flow and bureaucratic obstacles.

Employers' demand for labor differs from consumer demand for goods and services. Employers' demand for labor, depending on the increase of public demand for the goods it produces (Payaman, 1998, p. 89). If demand for goods increases then economic activity will be more developed. In macro, this economic improvement will affect the development of GRDP. Increasing GRDP in the next turn will lead to an increase in the number of workers who can be absorbed by GDP sectors. The relationship between the growths of the number of workers who can be absorbed in the sectors of GRDP with GRDP growth is the elasticity of labor absorption. The greater the elasticity of labor absorption indicates less unemployment.

For the workforce, the employer's demand for his workforce depends on the level of wages offered. The high level of wage earned by the workforce depends on the shape of the labor market. In a perfectly competitive market situation, if the low wages of many workers will not work. On the contrary, supply of labor will be increased if the wages offered are high. In imperfect competition markets, where the number of labor supply is large enough, employers can determine wages unilaterally. No workforce either in perfect or imperfect competition markets will affect the unemployment rate. Wages are basically the main source of one's income. Therefore, wages should be sufficient to meet the needs of workers and their families with reasonable that can meet the minimum requirements.

This research knowing how the influence of urbanization, industrialization, proportion of senior high school work force, the elasticity of labor absorption and provincial minimum wage to unemployment rate in Indonesia.

\section{Literature Review}

In the economic literature prior to the Great Depression 1930 (Todaro, 2000, p. 254) unemployment is usually regarded as an unadjusted condition rather than a temporary supply and demand of workers. Unemployment can be seen from both the demand side and the supply side. http://www.bized.ac.uk/virtualEconomicPolicyoutcomes/unemployment/unempex.html

First, the demand-side of unemployment is caused by a lack of aggregate demand, does not require a large number of workers. Secondly, supply-side is the result of labor market imperfections. In addition the supply side of unemployment can occur due to the presence of position or geographical mobility.

This is due to unfavorable information about job opportunities, which causes a person to take a long time to get a job, and consequently increase unemployment.

In a perfect labor market, supply will be the same as demand. Therefore all job seekers will get a job. However, if the market is not perfect then there will be unemployment. This can be described based on the Figure below:

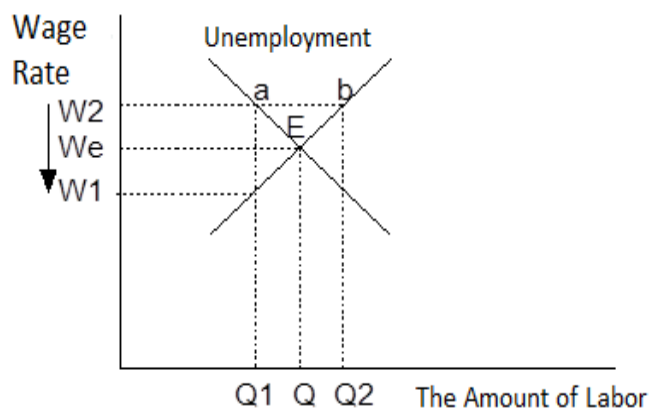

Figure 1. Perfect labor market

The Weak equity rate will be the same amount of labor supply provided by the individual to the employment demand posed by the entrepreneur. At high wage levels, i.e. at point $W 2$, (supply more than demand) and there is competition among job seekers that will push the wage rate down to the point We. At the lower wage level, at the point $\mathrm{Wl}$ the amount of labor demanded will exceed the quantity of supply and competition among entrepreneurs will push the wage rate up so as to reach its equilibrium point at $W e$, at the point of We that all work will be described by point $E$, at that wage level, everyone who wants to work will get his job. 
Developing countries need to change their domestic policies by involving job creation as their most important economic and social development objective. While developed countries need to review and change their traditional economic policies to the third world community, especially in the field of trade, foreign aid, and technology transfer (Todaro, 2000).

While the Post Keynesian considers hidden unemployment is also present in developing countries especially in the agricultural sector. According to Lewis the process of development begins and continues continuously as a result of replanting the profits created in the capitalist sector or the modern urban industrial sector with high productivity. If the capitalist sector gains, the funds will be reinvested by entrepreneurs. This activity will create a number of job opportunities in the capitalist sector. The production of this sector is increasing and thus economic development is created. The labor of the capitalist sector is increasing in number. And the growth of the capitalist sector will attract labor and the traditional rural subsistence sector. This process will continue so that there will be no more labor (Todaro, 2000, p. 326).

The two-sector model from Lewis above provides limited guidance and policy guidelines for solving employment and migration problems in developing countries, including Indonesia. This is due to the fact that in developing countries almost all modern technological changes, tend to be labor-saving, the absence of labor surplus in rural areas, the surplus of urban labor continues to increase, and urban wage rates tend to increase rapidly even though the rate of unemployment in urban (Arsyad, 1992, p. 241).

Ranis and Fei who developed the Lewis theory further differentiated the process of economic development in three stages. The first stage, the amount of labor is still excessive and this situation resulted in marginal productivity in the agricultural sector zero. The second stage is the stage where the excess labor is no longer available, but there is still unemployment. In the first and second stages, workers receive institutional. In the third stage, the marginal productivity of the agricultural sector has exceeded the level of institutional wages and caused labor in the agricultural sector to receive higher wages. At this stage, the wages received are equal to the marginal productivity of the sector. The third stage is the end of the take-off and then the economy will experience self-sustained growth.

Both Lewis and Ranis and Pei's theories see unemployment from the side of labor surplus in the agricultural sector, while on the other hand the urban industrial sector with high capital accumulation can absorb labor. But unemployment is not only caused by it. Unemployment can also be caused by educational problems (Santosa, 1987). This model has three basic assumptions (Arsyad, 1992, p. 239).

First, the model implicitly assumes that the rate of labor migration and the rate of employment creation in the urban sector is proportional to the rate of capital accumulation in urban areas. The faster the rate of capital accumulation, the higher the rate of growth of the modern sector and the higher the rate of creation of new labor. The profit surplus of the owners of capital is always reinvested.

Secondly, this model assumes a "surplus" of labor occurs in rural areas whereas in urban areas there are many employment opportunities. Almost all current research shows the opposite is happening that is a lot of open unemployment occurs in urban areas but there is only a small surplus of labor in rural areas.

Third, the assumption that real wages in urban areas will always remain the same up to a point where supply of surplus labor is exhausted. One interesting feature of the urban labor market and the determination of wage rates in almost all developing countries is the tendency that wage rates increase significantly over time, both in absolute value and in comparison with the average rural incomes, despite an increase in the unemployment rate.

The Todaro model (Arsyad, 1992, p. 243) says that the movement of workers from rural to urban areas is not due to job opportunities in the city, but because of the perception that wages in cities are larger than in villages. The bigger the difference in wages between the villages and the cities, the more daring they take the risk to move to the city in the hope of getting a better life than in the village.

\section{Research Methods}

This study looks at the effect of urbanization rate, industrialization level, senior high school workforce education, employment absorption and provincial minimum wage to unemployment rate in Indonesia in 2000. The data used are secondary data taken from the population census labor force (BPS) in 2000, GRDP data by province in 2000 and Minimum Wage of each Province in 2000. The method of analysis used in this research is quantitative method by using descriptive analysis technique and multiple linear regression to see unemployment rate between provinces and tendency of relation between dependent variables and independent variables. The variables were analyzed quantitatively by using multiple regression analysis, i.e.:

$$
Y=f(X 1, X 2, X 3, X 4, X 5)
$$


If expressed by the model of regression line equation becomes:

Description:

$$
Y=b_{o}+b_{1} X_{1}+b_{2} X_{2}+b_{3} X_{3}+b_{4} X_{4}+b 5 X 5+e^{2 l}
$$

$\mathrm{Y}=$ Unemployment rate

$\mathrm{X} 1=$ Urbanization rate

$\mathrm{X} 2=$ Industrialization rate

$\mathrm{X} 3=$ Proportion of High School Work Force and above

$\mathrm{X} 4=$ Elasticity of labor absorption

$\mathrm{X} 5=$ Provincial Minimum Wage

b, b1, b2, b3, b4, b5 = parameter, e = error term

Parameter of this model is calculated by using OLS model (Ordinary Least Square) and need to do statistical test with $T$-test and F-test. T-test is used to find the significant partial regression coefficient and F-test to find out the regression coefficient totally. Descriptive analysis is divided into two parts. First descriptive of independent variables. The tendency of each independent variable to the national average. Second, the relationship between unemployment rate and free variable is using Pearson correlation. The statistical criteria test is based on statistical prinsives which includes partial regression coefficient test, simultaneous regression coefficient and accuracy test of regression line.

Estimation result in this research is in the form of multicollinearity symptom test, heteroscedasticity and autocorrelation as follows: This test is performed in order to detect whether there is a perfect

Partial regression coefficient test is aimed to determine the influence of each independent variable to the dependent variable. Testing is done by using $t$-test. That is by comparing the value of $t$-count with $t$-table value. If the value of $t$-count is greater than $t$-table it can be concluded that the independent variable significant to the dependent variable, and if the value of $t$-count is smaller than $t$-table then independent variable does not significantly affect the dependent variable. The test of econometric criteria conducted on the model.

Relationship between one free variable with the other independent variable in the model. When there are symptoms of multi collinearity that cause the standard error is greater, allowing the interpretation of bias or conclusions will be mistaken.

Testing of multi colinierity is by comparing partial determinant coefficient (r2) with coefficient of determination $\left(\mathrm{R}^{2}\right)$. In addition to using this concept multicolinearity test can also be done by using the $\mathrm{d}$-max value or condition index and VIF value or variance inflation factor (Studenmund \& Belsley, 2003). Both of these tests can be directly tested together with regression results using the SPSS program.

The regression model will be free of multicollinearity if the VIF value is about 1 and the tolerance value is close to 1 (tolerance $=1 / \mathrm{VIF}$ ). Or if the value of the condition index or d-max is less than 60 . The d-max of 5 to 10 indicates a weak dependency and values between 30 and 100 indicate strong dependence. The d-max value of less than 60 indicates a tolerance limit along with regression results using the SPSS program.

\section{Results Analysis and Discussion}

This study there are five factors that affect unemployment, namely: the level of urbanization, the level of industrialization, the proportion of the senior high school workforce, the elasticity of employment and provincial minimum wage. In the first section try to look at descriptively each of these variables by comparing the national situation. Both want to prove the relationship between the five variables with the unemployment rate by using Linear Multiple regression

Description:

$$
Y=f(X 1, X 2, X 3, X 4, X 5)
$$

$\mathrm{Y}=$ Unemployment rate

$\mathrm{X} 1=$ Urbanization rate

$\mathrm{X} 2=$ Industrialization rate

$\mathrm{X} 3=$ Proportion of High School Work Force and above

$\mathrm{X} 4=$ Elasticity of labor absorption

$\mathrm{X} 5=$ Provincial Minimum Wage 
Table 6. Simple regression estimation result

\begin{tabular}{|c|c|c|c|c|c|}
\hline \multicolumn{2}{|l|}{ Variable } & Estimate & T - Value & Sig & VIF \\
\hline \multicolumn{2}{|l|}{ Constant } & 0,03918 & 3,166 & 0,004 & \\
\hline \multicolumn{2}{|l|}{ Urbanization rate $\left(\mathrm{X}_{1}\right)$} & $-0,01314$ & $-0,488$ & 0,630 & 3,613 \\
\hline \multicolumn{2}{|c|}{ Industrialization rate $\left(\mathrm{X}_{2}\right)$} & 0,006764 & 0,302 & 0,765 & 1,379 \\
\hline \multicolumn{2}{|c|}{ proportion of High School Work Force and above $+\left(\mathrm{X}_{3}\right)$} & 0,08097 & 2,312 & $\mathbf{0 , 0 3 0 * )}$ & 3,351 \\
\hline \multicolumn{2}{|c|}{ Elasticity of labor absorption $\left(\mathrm{X}_{4}\right)$} & 0,006337 & $-1,827$ & 0,080 & 1,284 \\
\hline \multicolumn{2}{|c|}{ Provincial Minimum Wage $\left(\mathrm{X}_{5}\right)$} & $-0,000000187$ & $-0,472$ & 0,641 & 1,696 \\
\hline $\mathrm{n}$ & $=30$ & & Prob $>$ F & & 0,020 \\
\hline F-Value & $=3,329$ & & $\alpha$ & & 0,05 \\
\hline R-Square & $=0,410$ & & DW & & 2,634 \\
\hline
\end{tabular}

Note. *) Significant.

Source: Research Data analyzed, 2015.

From the estimation result there are two variables that is urbanization and the proportion of high school workforce upward which is related in multi collinearity with unemployment rate therefore the next regression estimate by not include one variable having multi collinearity that is urbanization level. This election is based on the issuance of the senior high school workforce because this variable is the focus of discussion.

The results of the improved regression are as follows:

Table 7. Simple regression estimation results (with new data)

\begin{tabular}{|c|c|c|c|c|c|c|}
\hline \multicolumn{2}{|l|}{ Variable } & Estimate & \multicolumn{2}{|l|}{ T-Value } & \multirow{2}{*}{$\begin{array}{l}\text { Sig } \\
0,004\end{array}$} & \multirow[t]{2}{*}{ VIF } \\
\hline Constant & & 0,03918 & 3,166 & & & \\
\hline Industrialization ra & K2) & 0,006764 & 0,302 & & 0,765 & 1,223 \\
\hline High School Work & ce Proportion $+(\mathrm{X} 3)$ & 0,08097 & 2,312 & & $\mathbf{0 , 3 0 * )}$ & 1,749 \\
\hline Elasticity of labor & rption Labor Force (X4) & 0,006337 & $-1,827$ & & 0,080 & 1,105 \\
\hline Province minimun & ge (X5) & $-0,000000187$ & $-0,427$ & & 0,641 & 1,649 \\
\hline $\mathrm{n}$ & $=30$ & & Prob $>F$ & $=$ & 0,020 & \\
\hline F-Value & $=3.329$ & & $\alpha$ & $=$ & 0,05 & \\
\hline R-Square & $=0.410$ & & DW & $=$ & 2,634 & \\
\hline
\end{tabular}

Note. *) Significant.

Source: Research Data analyzed, 2015.

As noted in the methodology chapter, the multi colinearity problem is tested using the VIF value. The regression model will be free of multi colinearity if the VIF value is about 1 and the tolerance value is close to 1 (tolerance $=1 /$ VIF). Or if the value of the condition index or d-max is less than 60. The d-max value of 5 to 10 indicates a weak dependency and values between 30 and 100 indicate strong dependence. The d-max value of less than 60 indicates the tolerance limit.

The number $\mathrm{R}^{2}$ or $\mathrm{R}$ Square of 0.410 , this means $41 \%$ unemployment rate can be explained by variables, industrialization rate, the proportion of senior high school work force, the employment elasticity and provincial minimum wage, while the remaining $59 \%$ is explained by other variables beyond the independent variable. From the Anova test or $F$ test obtained $F$ count is 3.329 with a significance level of 0.020 because the probability ( $p$-value $=0.020)$ is much smaller than $\alpha=0.05$, then the regression model can show free variables together have influence against unemployment.

\subsection{The Relationship of Urbanization and Unemployment}

Regression results and also Pearson correlation results indicate that the relationship level of urbanization and unemployment rate is not significant. This result rejects the hypothesis that there is a positive relationship between the level of urbanization and the unemployment rate. The insignificance of this relationship, the percentage of provinces with few and less precise indicators, especially in the regression results, is thought to be caused by a national average of low urbanization rates, and this low number has little effect on unemployment.

Therefore, although statistically indicate a state that is not significant, but rationally can be said urbanization affect unemployment. The findings of BPS support this fact. The urban unemployment rate is quite large at $6.42 \%$ versus the rural unemployment rate of only $4.14 \%$. Indeed, the urban unemployment rate is not only contributed 
by urbanization figures, but also because of the growing number of uneducated labor force in employment. More research is needed to address this issue.

\subsection{Industrialization and Unemployment Relations}

As found in urbanization, the effect of industrialization with unemployment is also insignificant. The hypothesized both have a significant relationship. Regression coefficient number is very small that is equal to 0.006764 . If there is a change in unemployment rate of $100 \%$ then there will be a change in industrialization rate of $0.67 \%$. Thus the ability of industrialization in reducing unemployment is low.

Looking at the findings of the field, the role of the industrial sector in the absorption of labor is relatively low at $8.20 \%$ compared to the agricultural sector and the Services sector (see Table 2). Therefore Lewis's statement that excess labor in the agricultural sector can be diverted and contributed to the urban industrial sector in reality in developing countries is very limited. This is because the industrial sector relies heavily on capital accumulation and high technology (Kuncoro, 1987). In addition, industrialization strategies tend to use highly educated and skilled workers.

\subsection{Relationship Proportion of High School Work Force and the Unemployment Rate}

Both regression and Pearson correlation results, the proportion of the senior high school workforce with the unemployment rate indicates a significant relationship between the two. The regression coefficient number 0.08097 shows every $1 \%$ additional high school workforce hence unemployment rate will increase by $0,08 \%$. While the Pearson correlation coefficient number shows every $1 \%$ increase in senior high school upwards will increase unemployment by $0,514 \%$. These findings support the 2000 Population Census results that the unemployment rate of the senior high school workforce is $4.18 \%$ in the city and $0.64 \%$ in the village (Rosmiyati, 2003). The findings in the field show that educated unemployment is concentrated in high school work force group reaching $9.94 \%$ and university $6.91 \%$.

With the growth of the population is still quite high and also the growth of the workforce graduated high school graduation and on an increasingly feared if the high school workforce above this work does not work then the unemployment rate will increase. The non-employment of this group workforce is not only because they are not accommodated in the work field. They do not want to work with jobs that do not suit their aspirational education.

Therefore, a shift in the educated workforce in an area should receive special attention because it can increase unemployment and also will cause social problems and poverty that will affect the economy of a country.

\subsection{Employment and Unemployment Relationship}

Regression results show that the elasticity of labor absorption does not affect the unemployment rate significantly. However, Pearson's correlation shows that there is a significant relationship between employment elasticity and unemployment rate.

The correlation coefficient number -0.370 shows the relationship between the two variables is negative. If employment elasticity rises $10 \%$, then the unemployment rate will fall by $3.70 \%$. The findings of Pearson's correlation support the theory of elasticity. The elasticity of employment itself is the ratio between the rate of employment growth and the rate of growth of national income.

The decline in unemployment due to increased employment in the informal sector. Field findings indicate that the role of the informal sector in Indonesia is quite high in employment in 2000, $77.80 \%$ in rural areas and $42.88 \%$ in urban areas. The existence of the informal sector is indeed a safety valve for the growing number of labor forces looking to work and find work.

\subsection{Provincial Minimum Wages and Unemployment}

Rate with a significance level of $95 \%(\alpha=0.05)$ the provincial minimum wage has no significant effect. With a very small regression coefficient of -0.00000001872 , Provincial Minimum Wages have almost no effect on changes in the unemployment rate in Indonesia. If there is a provincial Minimum Wage increase of $100 \%$, then there will be a decrease in the unemployment rate of $0.001 \% 1872 \%$. This finding may mean that the current Minimum Provincial Wages do not attract people to work, especially for those with high school education and above.

\section{Conclusion and Suggestion}

\subsection{Conclusion}

In this study it can be concluded that:

1) Of the five variables that affect the unemployment rate only the proportion of senior high school work force 
and above have a positive and significant impact on unemployment in Indonesia, while other variables are not significant.

2) Variable Level of Urbanization has negative and not significant effect on unemployment rate. Not significant this relationship, especially in the results of regression caused, nationally the average level of urbanization is low, the second the influence of other independent variables that affect the calculation results.

3) The variables of industrialization rate have a positive effect, and are not significant to the unemployment rate, thus the industry's ability to reduce unemployment is low compared to the agricultural and service sectors.

4) Labor absorption elasticity variable has a negative and not significant effect on unemployment rate. Regression results show that the elasticity of labor absorption does not affect the unemployment rate significantly. However, Pearson's correlation shows that there is a significant relationship between employment elasticity and unemployment rate.

5) The provincial minimum wage variable has a negative and insignificant effect on the unemployment rate, which means that the current minimum wage does not attract people to work especially for those with high school education and above.

\subsection{Suggestion}

The suggestion of this research are: In order to overcome the unemployment rate in Indonesia other than the role of government also the role of private sector can play a role in tackling the problem of unemployment. In this case the public and private sectors can provide information on job market types of work required. Efforts to prevent or reduce the flow of urbanization workers to the city can be done by expanding or opening new employment in the village, for it required government policy to build the village.

\section{References}

Arsyad, L. (1992). Development Economics. STIE YKPN Yogyakarta.

Baker, Z., \& Manning, C. (1984). Labor Forces in Indonesia Participation, Employment Opportunities and Unemployment. CV Raja Wali Jakarta.

BPS. (2001). Statistics Indonesia. Central Bureau of Statistics, Jakarta, Indonesia.

BPS. (February 2001). Section Employment Statistics, BPS.

CPM. (2000). National Labor Force Survey (SAKERNAS) 1999. Labor statistics section, BPS.

Dody, S. (1997). Employment Unemployment Analysis Educated by Approach of Search Theory at Job Market in Central Java. Graduate Thesis, Unsyiah Aceh.

Iwan, P. (1993). Prism, Unemployment and Half of Urban Unemployment.

Jhingan, M. L. (1999). Development Economy and Planning. PT Raja Grafindo Persida Jakarta.

Juaro, \& Umar. (1983). Prism, Human Resources Remaining Agenda, Lp3ES.

Regional Office of the Department of Manpower of South Sumatra Province. (1998). Identification of Unemployment in Second Level Region of South Sumatera Province.

Simanjuntak, P. J. (1998). Human Resources Economics Institute Fe Univ Publishers, Indonesia.

Sukirno, S. (1994). Introduction to Micro Economic Theory. PT Raja Granfindo Persada Jakarta.

Syamsuddin, H. M. (1994). The Search Theory Application Against Labor Unemployment Educated on the Job Market in Sumatra. Thesis (Not Published).

Tadjuddin, N. E. (1995). Human Resources Employment Opportunities and Poverty. PT. Tiara Wacana Yogya.

Todaro, \& Michael. (1998). Economic Development in the Third World. Pt Glora Aksara Pratama.

\section{Copyrights}

Copyright for this article is retained by the author(s), with first publication rights granted to the journal.

This is an open-access article distributed under the terms and conditions of the Creative Commons Attribution license (http://creativecommons.org/licenses/by/4.0/). 